\title{
Trophic niche differentiation and utilisation of food resources in Collembola is altered by rainforest conversion to plantation systems
}

\author{
Winda Ika Susanti ${ }^{\text {Corresp., 1, } 2}$, Rahayu Widyastuti ${ }^{2}$, Stefan Scheu ${ }^{1,3}$, Anton Potapov ${ }^{1,4}$ \\ 1 J.F. Blumenbach Institute of Zoology and Anthropology, Georg-August Universität Göttingen, Göttingen, Germany \\ 2 Department of Soil Science and Land Resources, Bogor Institute of Agriculture, Bogor, Indonesia \\ 3 Center of Biodiversity and Sustainable Land Use, Göttingen, Germany \\ 4 A.N. Severtsov Institute of Ecology and Evolution, Russian Academy of Science, Moscow, Rusia \\ Corresponding Author: Winda Ika Susanti \\ Email address: winda.ika-susanti@biologie.uni-goettingen.de
}

Intensively managed monoculture plantations are increasingly replacing natural forests across the tropics resulting in changes in ecological niches of species and communities, and in ecosystem functioning. Collembola are among the most abundant arthropods inhabiting the belowground system sensitively responding to changes in vegetation and soil conditions. However, most studies on the response of Collembola to land-use change were conducted in temperate ecosystems and focused on shifts in community composition or morphological traits, while parameters more closely linked to ecosystem functioning, such as trophic niches, received little attention. Here, we used stable isotope analysis $\left({ }^{13} \mathrm{C}\right.$ and ${ }^{15} \mathrm{~N}$ ) to investigate changes in the trophic structure and use of food resources by Collembola in Jambi province (Sumatra, Indonesia), a region that experienced strong deforestation in the last decades. Isotopic values of Collembola from 32 sites representing four land-use systems were analyzed (rainforest, rubber agroforest, rubber (Hevea brasiliansis) and oil palm (Elaeis guineensis) monoculture plantations). Across Collembola species $\Delta^{13} \mathrm{C}$ values were highest in rainforest suggesting more pronounced processing of litter resources by microorganisms and consumption of these microorganisms by Collembola in this system. Lower $\Delta^{13} \mathrm{C}$ values, but high $\Delta^{13} \mathrm{C}$ variation in Collembola in oil palm plantations indicated that Collembola shifted towards herbivory and used more variable resources in this system. Small range in $\Delta^{15} \mathrm{~N}$ values in Collembola species in monoculture plantations in comparison to rainforest indicated that conversion of rainforest into plantations is associated with simplification in the trophic structure of Collembola communities. This was further confirmed by generally lower isotopic niche differentiation among species in plantations. Across the studied ecosystems, atmobiotic species 
(Symphypleona and Paronellidae) occupied the lowest, whereas euedaphic Collembola species occupied the highest trophic position, resembling patterns in temperate forests.

Some species of Paronellidae in rainforest and jungle rubber had $\Delta^{15} \mathrm{~N}$ values below those of leaf litter suggesting algivory (Salina sp.1, Callyntrura sp.1 and Lepidonella sp.1), while a dominant species, Pseudosinella sp.1, had the highest $\Delta^{15} \mathrm{~N}$ values in most of the landuse systems suggesting that this species at least in part lives as predator or scavenger. Overall, the results suggest that rainforest conversion into plantation systems is associated with marked shifts in the structure of trophic niches in soil and litter Collembola with potential consequences for ecosystem functioning and food-web stability. 


\title{
TROPHIC NICHE DIFFERENTIATION AND UTILISATION OF FOOD RESOURCES IN COLLEMBOLA IS ALTERED BY RAINFOREST CONVERSION TO PLANTATION SYSTEMS
}

\author{
Winda Ika Susanti, ${ }^{1,2,}$, Rahayu Widyastuti ${ }^{2}$, Stefan Scheu ${ }^{1,3}$, Anton Potapov $^{1,4}$ \\ 1J.F. Blumenbach Institute of Zoology and Anthropology, Georg-August Universität Göttingen, \\ Göttingen, Germany \\ ${ }^{2}$ Department of Soil Sciences and Land Resources, Bogor Institute of Agriculture, Bogor, Indonesia \\ ${ }^{3}$ Centre of Biodiversity and Sustainable Land Use, Göttingen, Germany \\ ${ }^{4}$ A.N. Severtsov Institute of Ecology and Evolution, Russian Academy of Sciences, Moscow, Russia
}

Corresponding Author

Winda Susanti

Untere Karspüle 2, 37073 Göttingen, Germany

Email address: winda.ika-susanti@biologie.uni-goettingen.de

\begin{abstract}
Intensively managed monoculture plantations are increasingly replacing natural forests across the tropics resulting in changes in ecological niches of species and communities, and in ecosystem functioning. Collembola are among the most abundant arthropods inhabiting the belowground system sensitively responding to changes in vegetation and soil conditions. However, most studies on the response of Collembola to land-use change were conducted in temperate ecosystems and focused on shifts in community composition or morphological traits, while parameters more closely linked to ecosystem functioning, such as trophic niches, received little attention. Here, we used stable isotope analysis $\left({ }^{13} \mathrm{C}\right.$ and $\left.{ }^{15} \mathrm{~N}\right)$ to investigate changes in the trophic structure and use of food resources by Collembola in Jambi province (Sumatra, Indonesia), a region that experienced strong deforestation in the last decades. Isotopic values of Collembola
\end{abstract}


28 from 32 sites representing four land-use systems were analyzed (rainforest, rubber agroforest, rubber (Hevea brasiliansis) and oil palm (Elaeis guineensis) monoculture plantations). Across Collembola species $\Delta^{13} \mathrm{C}$ values were highest in rainforest suggesting more pronounced processing of litter resources by microorganisms and consumption of these microorganisms by Collembola in this system. Lower $\Delta^{13} \mathrm{C}$ values, but high $\Delta^{13} \mathrm{C}$ variation in Collembola in oil palm plantations indicated that Collembola shifted towards herbivory and used more variable resources in this system. Small range in $\Delta^{15} \mathrm{~N}$ values in Collembola species in monoculture plantations in comparison to rainforest indicated that conversion of rainforest into plantations is associated with simplification in the trophic structure of Collembola communities. This was further confirmed by generally lower isotopic niche differentiation among species in plantations. Across the studied ecosystems, atmobiotic species (Symphypleona and Paronellidae) occupied the lowest, whereas euedaphic Collembola species occupied the highest trophic position, resembling patterns in temperate forests. Some species of Paronellidae in rainforest and jungle rubber had $\Delta^{15} \mathrm{~N}$ values below those of leaf litter suggesting algivory (Salina sp.1, Callyntrura sp.1 and Lepidonella sp.1), while a dominant species, Pseudosinella sp.1, had the highest $\Delta^{15} \mathrm{~N}$ values in most of the land-use systems suggesting that this species at least in part lives as predator or scavenger. Overall, the results suggest that rainforest conversion into plantation systems is associated with marked shifts in the structure of trophic niches in soil and litter Collembola with potential consequences for ecosystem functioning and food-web stability.

Key words: rainforest, oil palm, rubber, land-use change, stable isotope analysis, trophic niches, springtail 


\section{Introduction}

52

53

54

55

56

57

58

59

60

61

62

Agricultural intensification in Indonesia is associated with deforestation which increased strongly in the last 30 years (Koh \& Ghazoul, 2010 ; Gatto et al., 2015). Large parts of rainforest in lowland Sumatra (Indonesia) have been converted into oil palm (Elaeis guineensis) (16\% of total area) and rubber plantations (Hevea brasiliansis) (12\%) (Gatto et al., 2015). These processes are driven by the high global demand for agricultural products, and positively affect income and employment of local smallholders (Grass et al., 2020; Qaim et al., 2020). At the same time, conversion of tropical rainforest into plantation systems is associated with major changes in ecological niches of animal species, loss of biodiversity, and thereby with changes in ecosystem functioning (Barnes et al., 2014; Clough et al., 2016; Fitzherbert et al., 2008; Gilbert, 2012). These changes affect both the above- and belowground system. Complex and diverse microbial and animal communities in soil regulate important ecosystem functions and support aboveground life (Bardgett \& Van Der Putten, 2014), but knowledge on effects of land-use change on soil life in the tropics is very limited.

Studies from Sumatra showed that conversion of rainforest into oil palm and rubber plantations is associated with a decline in species diversity, population density, biomass and energy flux in litter macroinvertebrate communities by approximately 45\% (Drescher et al., 2016; Grass et al., 2020). Uneven decline in energy flux across size classes and trophic levels was documented for meso- and macrofauna soil communities leading to strong alterations in soil food-web structure (Potapov et al., 2019). Different basal resources available in different landuse systems result in changes in trophic niches of decomposer and predatory soil invertebrates, and results in reduced abundance of primary decomposers and in soil animals shifting their 
73 feeding habits towards herbivory (Klarner et al., 2017; Krause et al., 2019; Susanti et al., 2019).

Land-use change may also result in reduced trophic niche differentiation among species in belowground communities (Korotkevich et al., 2018), but this has not been investigated in tropical ecosystems.

Collembola are among the most abundant soil decomposer invertebrates, inhabiting various organic substrates and using a wide range of food resources (Rusek, 1998). Early studies on food resources of Collembola concluded that the majority of euedaphic and hemiedaphic species feed unselectively on a wide variety of food materials (Hopkin, 1997). However, stable isotope analysis showed pronounced trophic niche differentiation among Collembola species in temperate forests (Chahartagi et al., 2005). This differentiation in large has been explained by the taxonomic identity and life forms of Collembola (Potapov et al., 2016). Species, living aboveground and on the litter surface (atmobiotic and epedaphic life forms) are mainly phycophages, feeding on lichens, algae and pollen. Species, living in the litter (hemiedaphic life form) are detritivores feeding on saprotrophic microorganisms and litter. Species, living in soil (euedaphic life form) feed on soil organic matter, roots and fungi (Ponge, 2000; Potapov et al., 2016). Further, food resources and trophic levels also vary among high-rank taxa with e.g., Poduromorpha occupying higher trophic positions than Entomobryomorpha and Symphypleona, suggesting evolutionary selection for microbivory in the former (Potapov et al., 2016). Since lowland tropical forest ecosystems often have a less pronounced organic layer and different plant and animal community composition than temperate forest ecosystems (Petersen and Luxton, 1982), they provide different ecological niches for Collembola, potentially resulting in a different trophic structure of communities. To date, information on food resources and trophic niches of 
95

96

97

98

99

100

101

102

103

104

105

106

107

108

109

110

111

112

113

114

115

116

Collembola is based on studies from temperate ecosystems, whereas information from tropical ecosystems is virtually lacking entirely.

Over the last two decades, stable isotope analysis has become the most commonly used tool to assess trophic niches of soil animals (Potapov et al., 2019). Two isotopic ratios, ${ }^{13} \mathrm{C} /{ }^{12} \mathrm{C}$ (i.e., $\delta^{13} \mathrm{C}$ values) and ${ }^{15} \mathrm{~N} /{ }^{14} \mathrm{~N}$ (i.e., $\delta^{15} \mathrm{~N}$ values), typically are used in food-web studies. Trophic positions and length of trophic chains can be assessed using $\delta^{15} \mathrm{~N}$ values, whereas the range of $\delta^{13} \mathrm{C}$ values reflects variability in the use of basal resources (Potapov et al., 2019). Stable isotope composition of consumers follows that in food resources, thus allowing to reveal potential diet switching with land-use change (Klarner et al., 2017; Krause et al., 2019; Susanti et al., 2019).

Here, we use stable isotope analysis to investigate trophic positions and food resources of soil and litter Collembola in four different land-use systems in Sumatra, Indonesia: rainforest, rubber agroforest ('jungle rubber'), and monoculture rubber and oil palm plantations. The study aimed at investigating how trophic positions and food resources of Collembola change after rainforest conversion into agricultural plantations, such as rubber and oil palm, and, for the first time, at exploring patterns in trophic niche differentiation among tropical Collembola species. In more detail we investigated the following hypotheses:

1) Analogous to other soil invertebrates, Collembola shift their trophic niches towards herbivory in plantation systems in comparison to rainforest.

2) Due to reduced food resources (poor litter layer), the trophic niche width of Collembola is narrower in plantations in comparison to rainforest.

3) Trophic niche differentiation among Collembola species is more pronounced in rainforest than in plantation systems. 
4) Trophic niche differentiation among families and life forms of Collembola in tropical ecosystems follows similar patterns as in ecosystems of the temperate zone.

\section{Material and Methods}

Site description

Four land-use systems were investigated: lowland rainforest, jungle rubber, rubber and oil palm plantations, located in Jambi province, southwest Sumatra, Indonesia. The study sites were located at a similar altitude varying between 50 and $100 \mathrm{~m}$ a.s.l. in two landscapes, the Harapan and Bukit Dua Belas landscape; each land-use system was replicated four times per landscape, resulting in a total of 32 sites (for more details see Drescher et al., 2016). Lowland rainforest was used as reference, but represents secondary rainforest, which has been logged once by taking out large trees some 30 years ago. Jungle rubber represents a rubber agroforest system originating from rainforest enriched with rubber trees; the age of rubber trees varied between 15-40 years (Kotowska, Leuschner, Triadiati, Meriem, \& Hertel, 2015). Rubber and oil palm plantations were intensively managed monocultures of an average age of 7 to 16 and 8 to 15 years, respectively (Drescher et al., 2016), and were established after logging, clearing, and burning of either rainforest or jungle rubber. Soils at the Harapan landscape are loam Acrisols of low fertility, whereas in Bukit Dua Belas the major soil type is clay Acrisol (Allen et al., 2015; Kotowska et al., 2015). Management practices in these smallholder monoculture plantations are described in more detail in Allen et al. (2015). Oil palm plantations typically were fertilized once

137 in the rainy season and once in the dry season. Typically, 300-500 kg NPK complete fertilizer, 300 
139 plantations were weeded manually or chemically throughout the year. The most commonly used

140 herbicides were paraquat and glyphosate; these were applied at an average rate of 2 to $5 \mathrm{~L} \mathrm{ha}^{-1}$

$141 \mathrm{y}^{-1}$ (Allen et al., 2015; Clough et al., 2016; Kotowska et al., 2015).

142

143 Sampling procedure

Samples were taken in October 2013 in three $5 \times 5$ m subplots within $50 \times 50$ m plots established at each study site (Drescher et al., 2016). In each subplot soil samples of 16 x $16 \mathrm{~cm}$ were taken including the litter layer and the underlying top soil to a depth of $5 \mathrm{~cm}$. Animals from both layers were pooled for stable isotope analysis to obtain sufficient amount of animal tissue for the analyses. Animals were extracted by heat (Kempson et al., 1963) until the substrate was completely dry (6-8 days) using glycerol : water mixture at a ratio of $1: 1$ as collection solution. Field collection was conducted under the research permit No. 389/SIP/FRP/SM/X/2013 issued by the State Ministry of Research and Technology of Indonesia (RISTEK) with collection permit No. persons and organizations who granting us to access and use their properties: village leaders,

154 local plot owners, PT Humusindo, PT Perkebunan Nusantara VI, Harapan Rainforest, and Bukit 155 Duabelas National Park.

\section{Species identification}


identification, selected individuals were subsequently cleared in Nesbitt solution and mounted

on slides with Hoyer solution. Collembola were identified under a compound light microscope at

were used along with publications on Southeast Asian Collembola. Due to a relatively poorly

described fauna, in many cases we had to assign individuals to morphospecies without Linnaean

names (in total $72 \%$ of all identified species); for simplicity, we refer to both as 'species'. When

possible, juvenile specimens were ascribed to species of adults or subadults present in the same

sample or in samples from the same plot. After identification, all data on Collembola species and

their identification characters were uploaded to Ecotaxonomy database

(http://ecotaxonomy.org). In total 56 species from 13 families and 27 genera were found.

\section{Bulk stable isotope analyses}

Stable isotope ratios were- measured from dominant species representing at least $70 \%$ of the individuals on each plot (Supplementary Table S1 ). A number of rare species were observed only on few sites and such data would be not suitable for a proper analysis of the species and landuse effects and also for analytical facilities in the laboratory. Dominant species were chosen for each plot separately to represent the local 'functional community'. This selection procedure resulted in a total of 30 out of 56 species being included in the analysis across all land-use systems. For stable isotope measurements appropriate amounts of animal tissue (ranging from 0.003 to $1.268 \mathrm{mg}$ ) were transferred into tin capsules and dried at $60^{\circ} \mathrm{C}$ for $24 \mathrm{~h}$, weighed and stored in a desiccator until analysis. Stable isotope ratios, and total $\mathrm{C}$ and $\mathrm{N}$ concentration were 
180 determined using a coupled system consisting of an elemental analyzer (Eurovector, Milano,

181 Italy) equipped with a Blisotec autosampler (Blisotec, Jülich, Germany) and a Thermo Delta Vplus

182 isotope ratio mass spectrometer connected via a Conflo IV interface (both from Thermo Fisher

183 Scientific, Bremen, Germany) located at the Centre for Stable Isotope Research and Analysis,

184 Göttingen, Germany (Langel \& Dyckmans, 2014). Isotope signatures were expressed using the $\delta$

185 notation as $\delta \mathrm{X}(\% \mathrm{o})=\left(\mathrm{R}_{\text {sample }}-\mathrm{R}_{\text {standard }}\right) / \mathrm{R}_{\text {standard, }}$ with $\mathrm{X}$ representing the target isotope and $\mathrm{R}$ the

186 ratio of heavy to light isotope $\left({ }^{13} \mathrm{C} /{ }^{12} \mathrm{C}\right.$ or $\left.{ }^{15} \mathrm{~N} /{ }^{14} \mathrm{~N}\right)$. For $\delta^{15} \mathrm{~N}$ and $\delta^{13} \mathrm{C}$ analyses, $\mathrm{N}$ in atmospheric

187 air and Vienna Pee Dee Belemnite served as standards, respectively. We use IAEA CH6 (-10.43\%,

188 Sucrose) and IAEA 600 (-27.7\%o, Caffein) as C standards, and IAEA N1 (0.4\%o) and IAEA N2

$189(20.3 \%$ o) for $\mathrm{N}$ (both are Ammonium sulfates) for internal calibration.

\section{Statistical analysis}

193

To compensate for inter-site variation in the isotopic baseline, prior to the analysis all data were normalized to the local leaf litter using the following equations (Potapov et al., 2019):

$\Delta^{13} \mathrm{C}=\delta^{13} C_{\text {Collembola }}-\delta^{13} C_{\text {litter }}$

$\Delta^{15} N=\delta^{15} N_{\text {Collembola }}-\delta^{15} N_{\text {litter }}$

197 Stable isotope values of litter were taken from Klarner et al. (2017) who investigated the same 198 sampling sites. interface (R Studio, Inc.). First, we analyzed the effect of land-use system on the isotopic 
$202 \Delta \Delta^{15} \mathrm{~N}$ values of all measured Collembola individuals were tested using Linear Mixed Effect Models

203 (LMM) with species identity as random effect. Species identity was coded as random effect for

204 the following reasons: (1) In this first analysis we were not interested in variations in $\Delta^{13} \mathrm{C}$ and

$205 \Delta^{15} \mathrm{~N}$ values among species but still wanted to account for it, (2) species presence was uneven

206 across plots and land-use systems preventing the analysis of land-use effects, and (3) including

207 species as fixed factor would have compromised the analysis of land-use effects on $\Delta^{13} \mathrm{C}$ and $\Delta^{15} \mathrm{~N}$

208 values of Collembola by reducing error degrees of freedom. The analysis was conducted using

209 the Imer function in the Ime4 package (Bates et al., 2015). Significance of fixed effects (factors)

210 was tested using the Anova function in the car package. Significant differences in stable isotope

211 values between land-use systems were tested using the tukey test in the emmeans and

212 multicomp packages. We also analyzed the effect of land use only for one dominant species,

213 present in sufficient replicates in each land-use system (Pseudosinella sp.1) using analysis of

214 variance implemented in the aov function. Additionally, the ranges in $\Delta^{13} \mathrm{C}$ and $\Delta^{15} \mathrm{~N}$ values in

215 each land-use system were calculated as difference between minimum and maximum values and

216 visualized using the Kernel density estimation in the ggplot 2 package using the geom_violin

217 function.

Second, we assessed trophic niche differentiation among species by assessing the effect

of species identity on stable isotope composition of Collembola with LMM. We used species

221 as random effect to account for site-specific differences in trophic niches. The analysis was done

222 separately for each land-use system (eight analyses in total). Only species allowing more than

223 three measurements per land-use system were included. 
Third, we analyzed the effects of family identity and life form on stable isotope

225

226

227

228

229

230

231

232

233

234

235

236

237

composition of Collembola using LMM. Here, we used both plot and land-use system as random effects. Significant differences between families and life forms were tested using Tukey contrasts as implemented in the glth function in the multicomp package. To display the isotopic niche space of Collembola species, family, and lifeform, ellipses denoting $60 \%$ intervals were plotted using the standard.ellipse function in the siar package, and visualized using the ggplot and ggrepel packages. We also analyzed interactions between land-use system and life form and between land-use system and family with plot as random effect. In the analyses, we excluded Neanuridae and Onychiuridae as they were only represented by a single species not present in each of the land-use systems. In addition, we also analyzed R square values between species, family, and lifeform to identify the most important factor. Here, we used plot as random effect The analysis was done using the r.squaredGLMM function in the Ime4 and MuMin packages.

\section{Results}

Community-level changes with land use

In rainforest $\Delta^{13} \mathrm{C}$ values of Collembola ranged between 1.5 and $6.0 \%$ (total range $4.5 \%$ ), and in oil palm plantations between -1.5 and $8.5 \%$ (10.0\%o), indicating a wider range of $\Delta^{13} \mathrm{C}$ values in food resources in the latter. In jungle rubber and rubber plantations, the range of $\Delta^{13} \mathrm{C}$ values was similar to rainforest (between 1.0 and $6.0 \%$ ). Mean $\Delta^{13} \mathrm{C}$ values in rainforest were significantly higher than in plantation systems $\left(F_{3,146}=9.90, p=0.001\right.$; Fig. $1 \mathrm{~A}$, Supplementary Material Tables S2, S3). All $\delta^{13} \mathrm{C}$ values of Collembola species exceeded those of leaf litter except 
245 for one individual of Isotomiella cf. minor in oil palm plantations (Fig. 2; for details see

246 Supplementary Material Tables S6-S9).

247

In contrast to $\Delta^{13} \mathrm{C}$, the range of $\Delta^{15} \mathrm{~N}$ values was largest in rainforest (-5.0 to $19.0 \%$ ),

lowest in oil palm plantations (-1.0 to $8.0 \%$ ), and intermediate in rubber plantations (-5.0 to

$15.0 \%$ o) and in jungle rubber $\left(-7.5\right.$ to $16.0 \%$ o). Mean $\Delta^{15} \mathrm{~N}$ values of Collembola did not vary

Tables S4, S5). Stable isotope values of the most abundant Collembola species present in all land-

use systems, Pseudosinella sp.1, did not vary significantly among land-use systems both in $\Delta^{13} \mathrm{C}$

$\left(F_{3,21}=1.44, p=0.260\right)$ and $\Delta^{15} \mathrm{~N}\left(F_{3,21}=0.88, p=0.467\right)$.

Niche differentiation among species

$\Delta^{13} \mathrm{C}$ values across abundant species (represented by at least three measurements, see

Methods) varied significantly in rainforest $\left(F_{4,12}=6.34, p=0.005\right)$ and jungle rubber $\left(F_{5,17}=3.67\right.$,

$p=0.020)$, but not in rubber $\left(F_{5,19}=1.39, p=0.270\right)$ and oil palm plantations $\left(F_{2,9}=1.10, p=\right.$

0.370). In rainforest, $\Delta^{13} \mathrm{C}$ values of Pseudosinella sp.1 were highest and differed significantly

from those of Lepidocyrtus sp.1 and Pararrhopalites sp.1, whereas in jungle rubber they were

highest in Homidia cingula and differed significantly from Callyntrura sp.1.

262

$\Delta^{15} \mathrm{~N}$ values across abundant species varied significantly in rainforest $\left(F_{4,14}=5.00, p=\right.$

$0.010)$, jungle rubber $\left(F_{5,18}=4.70, p=0.006\right)$ and oil palm plantations $\left(F_{2,9}=23.59, p=0.001\right)$, but

not in rubber plantations $\left(F_{5,19}=2.43, p=0.072\right)$ (Fig. 3 ; for details see Supplementary Material

Tables S10-S13). In rainforest Pseudosinella sp.1 occupied the highest trophic position, followed 
266 by Isotomiella cf. minor, whereas Allacma sp.1 occupied the lowest trophic position. Similar to

267 rainforest, in jungle rubber Pseudosinella sp.1 also occupied the highest trophic position, but

$268 \Delta^{15} \mathrm{~N}$ values were lowest in Callyntrura sp.1. Overall, Pseudosinella sp.1, the most dominant

269 species, occupied the highest trophic position across all species. Across all samples analyzed (20

270 species in rainforest, 17 species jungle rubber, 15 species in rubber plantations, and 13 species

271 in oil palm plantations) $3 \%$ of the measurements had $\Delta^{15} \mathrm{~N}$ values below that of litter (see

272 Supplementary Material, Fig. 1).

273

274

Differences among Collembola life forms and families

275 The $\Delta^{15} \mathrm{~N}$ values of Collembola varied among life forms $\left(F_{24,126}=1.82, p=0.018\right)$, but this was not

276 the case for $\Delta^{13} C$ values $\left(F_{24,126}=1.19, p=0.260\right)$, with the interaction between lifeform and land-

277 use system neither being significant for $\Delta^{15} \mathrm{~N}\left(\mathrm{~F}_{9,132}=0.87, \mathrm{p}=0.556\right)$ nor for $\Delta^{13} \mathrm{C}\left(\mathrm{F}_{9,135}=0.79\right.$,

$278 p=0.619)$. Differences between life forms were more pronounced in rainforest and jungle rubber

279 and less in rubber and oil palm plantations (Fig. 4). Euedaphic species were generally most

280 enriched in ${ }^{15} \mathrm{~N}$, whereas atmobiotic species on average occupied the lowest trophic position

281 (except in rubber plantations), often having $\Delta^{15} \mathrm{~N}$ values below $5.0 \%$, with epedaphic and

282 hemiedaphic species being intermediate.

283

Similar to results of the life form analysis, the $\Delta^{15} \mathrm{~N}\left(\mathrm{~F}_{24,129}=2.19, \mathrm{p}=0.002\right)$ but not $\Delta^{13} \mathrm{C}$

values $\left(F_{24,128}=1.01, p=0.470\right)$ of Collembola varied significantly among families (Fig. 5$)$, with the interaction between family and land-use system neither being significant for $\Delta^{15} \mathrm{~N}\left(\mathrm{~F}_{8,122}=0.34\right.$, $p=0.945)$ nor for $\Delta^{13} C\left(F_{8,121}=1.84, p=0.075\right)$. Isotomidae and Entomobryidae occupied the highest trophic positions across land-use systems, Symphypleona occupied the lowest trophic 
288

289

290

291

292

293

294

295

296

297

298

299

300

301

302

303

304

305

306

307

308

309

position in rainforest and oil palm plantations, whereas in jungle rubber and rubber plantations the lowest trophic position was occupied by Paronellidae. Family and lifeform identity explained approximately two times less variation in $\Delta^{15} \mathrm{~N}$ values than species identity with $R^{2}=0.29$ in models based on species, and $\mathrm{R}^{2}=0.13$ in both models based on families and life forms.

\section{Discussion}

Variations in trophic niches with land-use system

Results of our study indicate that rainforest conversion into agricultural plantations is associated with changes in basal resources ( $\Delta^{13} \mathrm{C}$ values) of Collembola, but does not significantly affect their average trophic positions ( $\Delta^{15} \mathrm{~N}$ values). These findings are in line with the results of the study of Krause et al. (2019) investigating oribatid mites at the same study sites and showing that the shift in trophic niches to be mainly due to changes in the use of basal resources rather than trophic levels. Similar to previous studies on centipedes, oribatid mites and other soil animal taxa (Klarner et al., 2017; Susanti et al., 2019; Krause et al., 2019), we also found the conversion of rainforest into plantations to be associated in Collembola with a shift from detritivory towards herbivory (i.e., lower ${ }^{13} \mathrm{C}$ enrichment). In rainforest and jungle rubber, $\delta^{13} \mathrm{C}$ values of Collembola were $2.0-5.0 \%$ higher compared to leaf litter, which resembles the shift observed in temperate forest ecosystems (Pollierer et al., 2009). This "detrital shift" in $\delta^{13} \mathrm{C}$ (Potapov et al., 2019) presumably is due to acquiring $C$ from saprotrophic fungi and bacteria (Potapov et al., 2013) that preferentially use ${ }^{13} \mathrm{C}$-rich plant compounds (Pollierer et al., 2009). High ${ }^{13} \mathrm{C}$ enrichment in most of the studied Collembola species in more natural ecosystems (rainforest and jungle rubber) suggests that they predominantly rely on microorganisms decomposing organic matter rather 
310 than on fresh plant material as food source (Potapov et al., 2019). Overall, similar enrichment in

$311{ }^{13} \mathrm{C}$ and ${ }^{15} \mathrm{~N}$ in Collembola in temperate and tropical ecosystems suggest that Collembola rely little

312 on fresh plant material or mycorrhizal fungi in both, and this may well apply to soil food webs in

313 general.

As indicated by $\Delta^{13} \mathrm{C}$ values, Collembola species in oil palm plantations used food resources of a wide range of ${ }^{13} \mathrm{C}$ values, which was not the case in the other land-use systems studied. Variations in ${ }^{13} \mathrm{C}$ values of food resources in oil palm plantations may be attributed to the variety of management practices of the smallholder systems studied (Clough et al., 2016). Potentially, variations in organic inputs due to differences in weeding, herbicide, and fertilization practices, resulted in an overestimation of the trophic niche width in oil palm plantations lack of high trophic level (predators, scavengers) and low trophic level species (primary decomposers, specialized lichen feeders). This may reflect the dominance of generalist species in the disturbed habitat of oil palm plantations (Korotkevich et al., 2018). Nematode communities also indicated oil palm plantations to be the most disturbed of the four land-use systems studied (Krashevska et al., 2019). Further, Klarner et al. (2017) found $\Delta^{15} \mathrm{~N}$ values of centipede species to be lower in oil palm compared to jungle rubber and rubber plantations suggesting that trophic chains in oil palm plantations are shorter than in the other land-use systems studied. Overall, these findings suggest that the structure of soil food-webs in monoculture plantations, especially oil palm, is simplified due to reduced number of trophic levels. 
little with the conversion of rainforest into plantation systems. Pseudosinella sp.1 colonized both

litter and soil, and, as indicated by $\Delta^{15} \mathrm{~N}$ values, occupied the highest trophic position among all

mycrorrhizal fungi, which are enriched in ${ }^{15} \mathrm{~N}$ (Hobbie et al., 2001; Potapov \& Tiunov, 2016), and

/ or live as predators feeding e.g., on nematodes, which are similarly abundant across the landuse systems studied (Krashevska et al., 2019). Conversion of rainforest may have less affected the mineral soil- and root-based resources than litter resources, and this may explain the high abundance of euedaphic Pseudosinella sp.1 in plantations. Similarly, Krause et al. (2019) found the trophic niche of dominant species of oribatid mites to change little with the conversion of rainforest into plantations. This suggests that trophic niches of certain species may be little affected by land-use change despite strong changes in the overall food-web structure.

Trophic differentiation among species

347 and jungle rubber than in rubber and oil palm plantations. Korotkevich et al. (2018) also found the interspecific (in contrast to intraspecific) variation in trophic niches of Collembola to be higher in natural (forest and meadows) than in disturbed habitats (pastures and lawns). Among the Collembola species studied $\Delta^{13} \mathrm{C}$ values of Pseudosinella sp.1 in rainforest, and Callyntrura sp.1 and Sphyroteca sp.1 in jungle rubber differed significantly from those of other Collembola species 
352 indicating that these species are able to exploit resources not available to the other Collembola

353 species in the respective land-use system.

354 Similar to $\Delta^{13} \mathrm{C}$ values, Collembola species in each land-use system, except rubber 355 plantations, also differed in $\Delta^{15} \mathrm{~N}$ values. In jungle rubber Callyntrura sp.1 was most depleted in $356 \delta^{15} \mathrm{~N}$ among the studied Collembola species indicating that this species occupied the lowest 357 trophic position pointing to phycophagy (Potapov et al., 2018). In rainforest Pseudosinella sp.1 358 had the highest $\delta^{15} \mathrm{~N}$ values followed by Isotomiella cf. minor and Acrocyrtus sp. suggesting that

359 these species are as microbivores in undisturbed ecosystems. Overall, based on $\Delta^{13} \mathrm{C}$ and $\Delta^{15} \mathrm{~N}$ 360 values, trophic niche differentiation among species was most pronounced in rainforest, 361 presumably due to the availability of a wider spectrum of food resources and more stable 362 environmental conditions than in plantations. This is likely to result in more efficient food-web 363 functioning in natural ecosystems due to species complementarity (Loreau and Hector 2001), 364 which is partly lost in plantation systems.

Variations in isotopic niches of Collembola taxa and life forms with land-use systems indicating that these taxa feed on algae or lichens (Chahartaghi et al., 2005; Potapov et al., 2018). Symphypleona as well as Paronellidae are well adapted to aboveground life, both are large-sized and possess well-developed visual systems. Such 'atmobiotic' Collembola have been assumed to

371 live at least in part as herbivores on vascular plants or algae (Rusek, 2007). This suggestion is in

372 line with studies from temperate forests investigating variations in stable isotope ratios in 
373 Symphypleona (Chahartaghi et al., 2005; Potapov et al., 2016). Paronellidae predominantly occur

374 in tropical regions also living above the ground suggesting that the microhabitat they live in

375 defines feeding preferences of Collembola across different phylogenetic lineages (see life form

376 discussion below). Entomobryidae and Isotomidae occupied high trophic positions and this also

377 is consistent with earlier studies based on variations in stable isotope ratios suggesting that they

378 predominantly feed on microorganisms colonizing decomposing litter materials (Chahartaghi et

379 al., 2005; Potapov et al., 2016). Some species of these two families occupied very high trophic

380 positions resembling those of Onychiuridae and Neanuridae in temperate ecosystems suggesting

381 that at least in part they live as predators or scavengers, presumably including nematodes as prey

382 (Heidemann et al., 2014). Since Onychiuridae and Neanuridae were rare at our study sites,

383 species from other families might have been able to occupy their trophic niches.

Trophic niches of Collembola in our study varied with life form as shown previously for

temperate ecosystems (Ponge, 2000; Potapov et al., 2016). Conform to the patterns in

Collembola families, the results suggest that atmobiotic and epedaphic species occupied the

lowest trophic position across land-use systems, whereas euedaphic species such as

Pseudosinella sp.1 occupied the highest trophic position. This is in line with the results of the

study of Potapov et al. (2016) indicating that species inhabiting deeper soil layers (hemiedaphic and euedaphic) are more enriched in ${ }^{15} \mathrm{~N}$ than those living in litter and above the ground

(epedaphic and atmobiotic). High $\delta^{15} \mathrm{~N}$ values may result from feeding on ectomycorrhizal fungi

which are enriched in ${ }^{15} \mathrm{~N}$ (see above; Hobbie et al., 2001; Potapov and Tiunov, 2016), however,

this unlikely applies to tropical forests where trees predominantly form mutualistic interactions 
395 Collembola to algae or lichen feeding, which is widespread in Collembola in temperate forests

396 (Potapov et al., 2018), but in our study only few species had $\delta^{15} \mathrm{~N}$ values below those of litter.

397 This contradicts results based on fatty acid analysis suggesting that Collembola feed more on

398 algae in tropical than in temperate ecosystems (Susanti et al., 2019). To clarify the contribution

399 of algae in soil food webs in tropical and temperate ecosystems, more data on stable isotope

400 composition of various food resources in tropical forests, or direct experimentation, are needed.

401 Differences between life forms were more pronounced in rainforest and jungle rubber and less

402 in plantation systems, which may reflect the more pronounced litter layer in the former than the

403 latter (Krashevska et al. 2015). Overall, the results suggest that similar to oribatid mites (Tsurikov

404 et al., 2019) the trophic niche structure in Collembola communities in temperate and tropical

405 forests is generally similar and this is partly explained by taxonomic affiliation and life form.

406

407 Conclusion

408 We showed that the conversion of rainforest into agricultural plantations, such as rubber and oil 409 palm, is associated with changes in trophic niches of Collembola. The use of food resources 410 shifted towards herbivory, with the range of food resources of Collembola in oil palm plantations 411 being the highest, likely due to the heterogeneity in management. By contrast, the range of 412 trophic positions in oil palm plantations was low suggesting that the trophic structure is simplified 413 lacking high but also low trophic levels. This is further supported by the less pronounced trophic 414 niche differentiation among species in monoculture plantations. Similar to the pattern in oribatid 415 mites (Tsurikov et al., 2019), the structure of trophic niches in tropical Collembola communities 
416 resembled that in temperate forests. Life form and family identity explained about half of the

417 species-level variation; atmobiotic species occupied the lowest and euedaphic species the

418 highest trophic position, but the difference was less pronounced in plantations. Overall, the

419 results document that changes in community composition associated with the conversion of

420 rainforest into plantation systems are followed by shifts in the trophic structure and trophic

421 niches in Collembola communities, potentially compromising ecosystem functions and food-web

422 stability in plantations.

\section{Acknowledgements}

425 We thank the State Ministry of Research and Technology of Indonesia (RISTEK), the Indonesian

426 Institute of Sciences (LIPI), Ministry of Forestry (PHKA) and Restoration Ecosystem Indonesia

427 Harapan. We also thank the following persons and organizations: village leaders, local plot

428 owners, PT Humusindo, PT Perkebunan Nusantara VI, Harapan Rainforest, and Bukit Duabelas

429 National Park. We acknowledge support of the Open Access Publication Funds of the University 430 of Göttingen.

431

\section{References}

433 Allen, K., Corre, M. D., Tjoa, A., \& Veldkamp, E. (2015). Soil nitrogen-cycling responses to 434 conversion of lowland forests to oil palm and rubber plantations in Sumatra, Indonesia. $435 \quad$ PLOS ONE, 10(7), 1-21. https://doi.org/10.1371/journal.pone.0133325

436 Bardgett, R. D., \& Van Der Putten, W. H. (2014). Belowground biodiversity and ecosystem 
functioning. Nature, 515(7528), 505-511. https://doi.org/10.1038/nature13855

438

439

440

441

442

443

444

445

446

447

448

449

450

451

452

453

454

455

456

Barnes, A. D., Jochum, M., Mumme, S., Haneda, N. F., Farajallah, A., Widarto, T. H., \& Brose, U. (2014). Consequences of tropical land use for multitrophic biodiversity and ecosystem functioning. Nature Communications, 5, 1-7. https://doi.org/10.1038/ncomms6351

Bates, D., Maechler, M., Bolker, B., \& Walker, S. (2015). Fitting Linear Mixed-Effects Models Using Ime4. Journal of Statistical Software, 67(1), 1-48. https://doi.org/10.18637jjs.v067.i01

Chahartaghi, M., Langel, R., Scheu, S., \& Ruess, L. (2005). Feeding guilds in Collembola based on nitrogen stable isotope ratios. Soil Biology and Biochemistry, 37(9), 1718-1725. https://doi.org/10.1016/j.soilbio.2005.02.006

Clough, Y., Krishna, V. V., Corre, M. D., Darras, K., Denmead, L. H., Meijide, A., ... Scheu, S. (2016). Land-use choices follow profitability at the expense of ecological functions in Indonesian smallholder landscapes. Nature Communications, 7. https://doi.org/10.1038/ncomms13137

Drescher, J., Rembold, K., Allen, K., Beckscha“, P., Buchori, D., Clough, Y., ... Stefan Scheu. (2016). Ecological and socio-economic functions across tropical land use systems after rainforest conversion Ecological and socio-economic functions across tropical land use systems after rainforest conversion. (April). https://doi.org/10.1098/rstb.2015.0275

Fitzherbert, E. B., Struebig, M. J., Morel, A., Danielsen, F., Brühl, C. A., Donald, P. F., \& Phalan, B. (2008). How will oil palm expansion affect biodiversity? Trends in Ecology and Evolution, 
458

459

460

461

462

463

464

465

466

467

468

469

470

471

472

473

474

475

476

Gatto, M., Wollni, M., \& Qaim, M. (2015). Oil palm boom and land-use dynamics in Indonesia: The role of policies and socioeconomic factors. Land Use Policy, 46, 292-303. https://doi.org/10.1016/j.landusepol.2015.03.001

Gilbert, N. (2012). Palm-oil boom raises conservation concerns. Nature, 487(7405), 14-15. https://doi.org/10.1038/487014a

Grass, I., Kubitza, C., Krishna, V.V.(2020). Trade-offs between multifunctionality and profit in tropical smallholder landscapes. Nat Commun 11, 1186. https://doi.org/10.1038/s41467020-15013-5

Heidemann, K., Hennies, A., Schakowske, J., Blumenberg, L., Ruess, L., Scheu, S., \& Maraun, M. (2014). Free-living nematodes as prey for higher trophic levels of forest soil food webs. Oikos, 123(10), 1199-1211. https://doi.org/10.1111/j.1600-0706.2013.00872.x

Hobbie, E. A., Weber, N. S., \& Trappe, J. M. (2001). Mycorrhizal vs saprotrophic status of fungi: the isotopic evidence. New Phytologist, 601-610.

Hopkin, S. P. (1997). Biology of the springtails (Insecta, Collembola).

Kempson, D., Lloyd, M., \& Gheraldi, R. (1963). A new extractor for woodland litter. Pedobiologia, 3(1), 1-21.

Klarner, B., Winkelmann, H., Krashevska, V., Maraun, M., Widyastuti, R., \& Scheu, S. (2017). Trophic niches, diversity and community composition of invertebrate top predators (Chilopoda) as affected by conversion of tropical lowland rainforest in Sumatra (Indonesia). 
478

479

Koh, L. P., \& Ghazoul, J. (2010). Reply to Sloan and Stork: Spatially explicit scenario analysis for reconciling agricultural expansion, forest protection, and carbon conservation in Indonesia. Proceedings of the National Academy of Sciences, 107(45), E172-E172. https://doi.org/10.1073/pnas.1012681107

Korotkevich, A. Y., Potapov, A. M., Tiunov, A. V., Kuznetsova, N. A. (2018). Collapse of trophicniche structure in belowground communities under anthropogenic disturbance. Ecosphere, 9(12). https://doi.org/10.1002/ecs2.2528

Kotowska, M. M., Leuschner, C., Triadiati, T., Meriem, S., \& Hertel, D. (2015). Quantifying above- and belowground biomass carbon loss with forest conversion in tropical lowlands of Sumatra (Indonesia). Global Change Biology, 21(10), 3620-3634. https://doi.org/10.1111/gcb.12979

Krashevska, V., Kudrin, A. A., Widyastuti, R., \& Scheu, S. (2019). Changes in Nematode Communities and Functional Diversity With the Conversion of Rainforest Into Rubber and Oil Palm Plantations. 7(December), 1-10. https://doi.org/10.3389/fevo.2019.00487

Krause, A., Sandmann, D., Bluhm, S. L., Ermilov, S., Widyastuti, R., Haneda, N. F., ... Maraun, M. (2019). Shift in trophic niches of soil microarthropods with conversion of tropical rainforest into plantations as indicated by stable isotopes (15N, 13C). PLOS ONE, 14(10), 1-14. https://doi.org/10.1371/journal.pone.0224520

Loreau, M., Hector, A. (2001). Partitioning selection and complementarity in biodiversity 

experiments. Nature, 412: 72-76.

498

499

500

501

502

503

504

505

506

507

508

509

510

511

512

513

514

515

516

Petersen, H., Luxton, M. (1982). A comparative analysis of soil fauna populations and their role in decomposition processes. Oikos, 39:287-388.

Pollierer, M. M., Langel, R., Scheu, S., \& Maraun, M. (2009). Compartmentalization of the soil animal food web as indicated by dual analysis of stable isotope ratios (15N/14N and 13C/12C). Soil Biology and Biochemistry, 41(6), 1221-1226. https://doi.org/10.1016/j.soilbio.2009.03.002

Ponge, J. F. (2000). Vertical distribution of collembola (Hexapoda) and their food resources in organic horizons of beech forests. Biology and Fertility of Soils, 32(6), 508-522. https://doi.org/10.1007/s003740000285

Potapov, A. A., Semenina, E. E., Korotkevich, A. Y., Kuznetsova, N. A., \& Tiunov, A. V. (2016). Connecting taxonomy and ecology: Trophic niches of collembolans as related to taxonomic identity and life forms. Soil Biology and Biochemistry, 101, 20-31. https://doi.org/10.1016/j.soilbio.2016.07.002

Potapov, A.M., \& Tiunov, A. V. (2016). Stable isotope composition of mycophagous collembolans versus mycotrophic plants: do soil invertebrates feed on mycorrhizal fungi?. Soil Biology and Biochemistry, 93, 115-118.

Potapov, Anton M., Korotkevich, A. Y., \& Tiunov, A. V. (2018). Non-vascular plants as a food source for litter-dwelling Collembola: Field evidence. Pedobiologia, 66(December 2017), 11-17. https://doi.org/10.1016/j.pedobi.2017.12.005 
517 Potapov, Anton M., Semenina, E. E., Kurakov, A. V., \& Tiunov, A. V. (2013). Large 13C/12C and

518 small $15 \mathrm{~N} / 14 \mathrm{~N}$ isotope fractionation in an experimental detrital foodweb (litter-fungi-

519 collembolans). Ecological Research, 28(6), 1069-1079. https://doi.org/10.1007/s11284-

$520 \quad$ 013-1088-z

521 Potapov, Anton M., Tiunov, A. V., \& Scheu, S. (2019). Uncovering trophic positions and food

522 resources of soil animals using bulk natural stable isotope composition. Biological Reviews, 523 94(1), 37-59. https://doi.org/10.1111/brv.12434

524 Qaim, M., Sibhatu, K. T., Siregar, H., \& Grass, I. (2020). Environmental, Economic, and Social

525 Consequences of the Oil Palm Boom. Annual Review of Resource Economics, 12.

526 Rusek, J. (2007). A new classification of Collembola and Protura life forms. In: contribution to 527 soil zoology in central Europe II. ISB BC ASCR. Ceske Budejovice, 109-115.

528 Rusek, Josef. (1998). Biodiversity of Collembola and their functional role in the ecosystem.

529 Biodiversity and Conservation, 7(9), 1207-1219.

$530 \quad$ https://doi.org/10.1023/A:1008887817883

531 Suhardjono, Y. R., Deharveng, L., \& Bedos, A. (2012). Collembola (ekor pegas): Biologi, $532 \quad$ klasifikasi, ekologi.

533 Susanti, W. I., Pollierer, M. M., Widyastuti, R., Scheu, S., \& Potapov, A. (2019). Conversion of 534 rainforest to oil palm and rubber plantations alters energy channels in soil food webs.

$535 \quad$ Ecology and Evolution. https://doi.org/10.1002/ece3.5449

536 Tsurikov, S. M., Ermilov, S. G., \& Tiunov, A. V. (2019). Trophic structure of a tropical soil- and 
537 litter-dwelling oribatid mite community and consistency of trophic niches across biomes.

538 Experimental and Applied Acarology, 78(1), 29-48. https://doi.org/10.1007/s10493-019-

$539 \quad 00374-4$

540

541

542

543 


\section{Figure 1}

Variations in $\Delta^{13} \mathrm{C}$ and $\Delta^{15} \mathrm{~N}$ values of Collembola among the studied land-use systems (rainforest, jungle rubber, rubber and oil palm plantations)

Variations in $\Delta^{13} \mathrm{C}$ and $\Delta^{15} \mathrm{~N}$ values of Collembola among the studied land-use systems: (A) rainforest, (B) jungle rubber, (C) rubber and (D) oil palm plantations. Violin plots show frequency distribution of values (mirrored Kernel density estimation), all individual measurements are displayed together independent of taxonomic identity. ${ }^{*}$ Average $\Delta^{13} \mathrm{C}$ values in rainforest were significantly higher than in the other three land-use systems $(P<$ $0.05)$ 


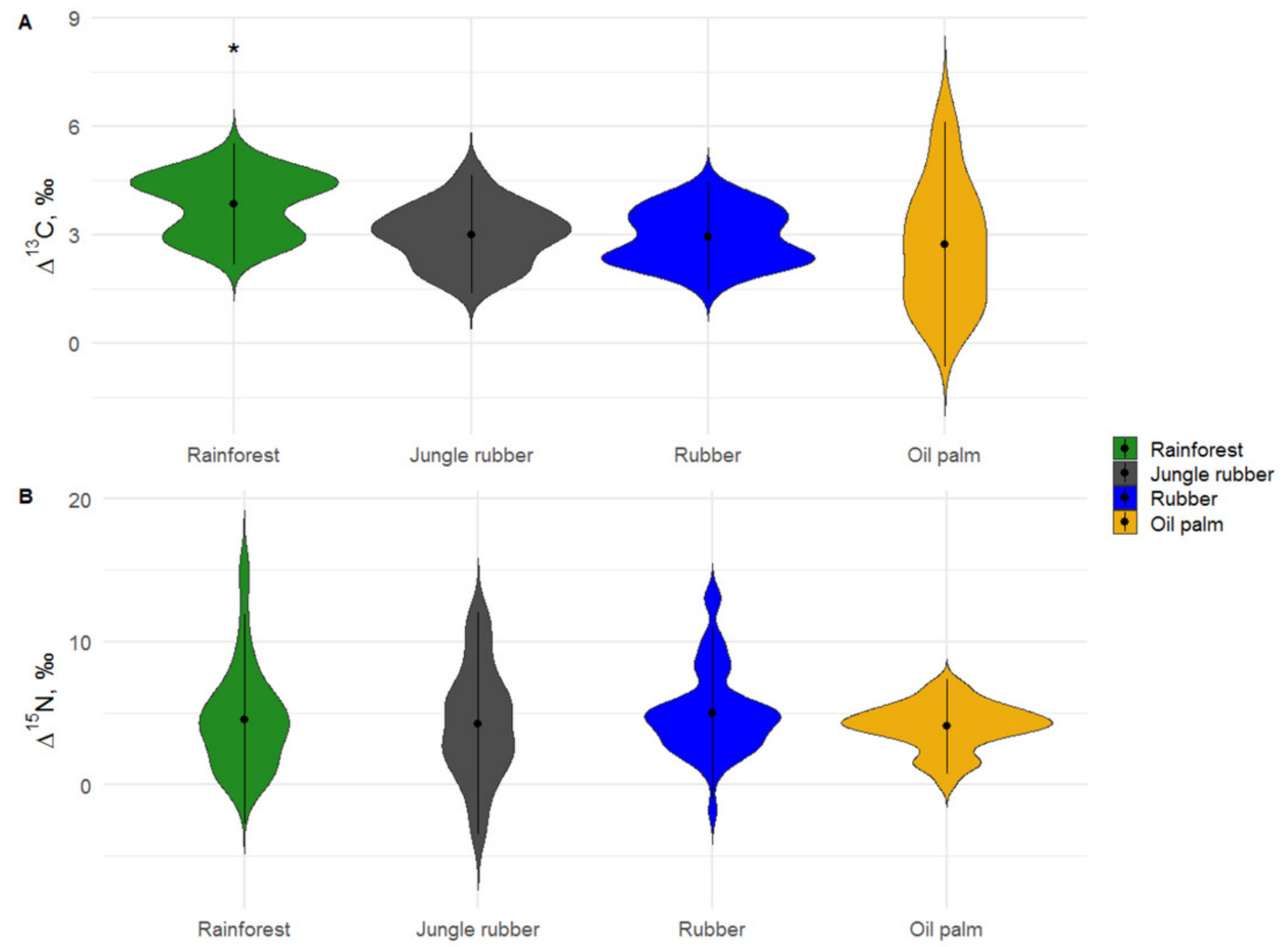




\section{Figure 2}

Differences of $\Delta^{13} \mathrm{C}$ values of Collembola species in different land-use systems (rainforest, jungle rubber, rubber and oil palm plantations)

Differences of $\Delta^{13} C$ values of Collembola species in different land-use systems: (A) rainforest, (B) jungle rubber, (C) rubber and (D) oil palm plantations; model-estimated means (Ismeans) with standard deviation. Horizontal stripes represent individual measurements. Only species with more than three replicates per land-use system were analyzed (see Methods). Isotope values of each species in each land-use system with the same letter are not significantly different according to Tukey's honestly significant difference test $(p>0.05)$ 

A. Rainforest
B. Jungle Rubber
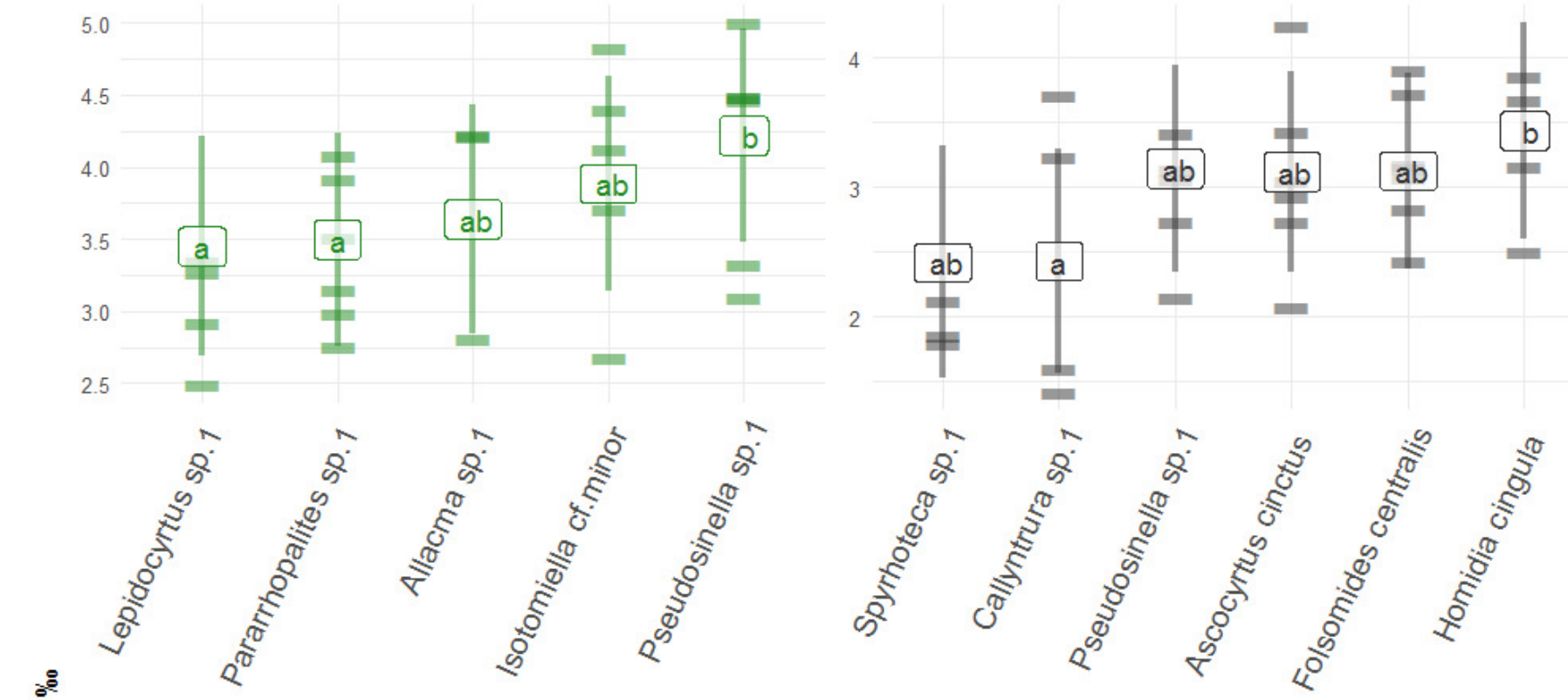

$\stackrel{5}{5}$

\section{Rubber}

D. Oil Palm

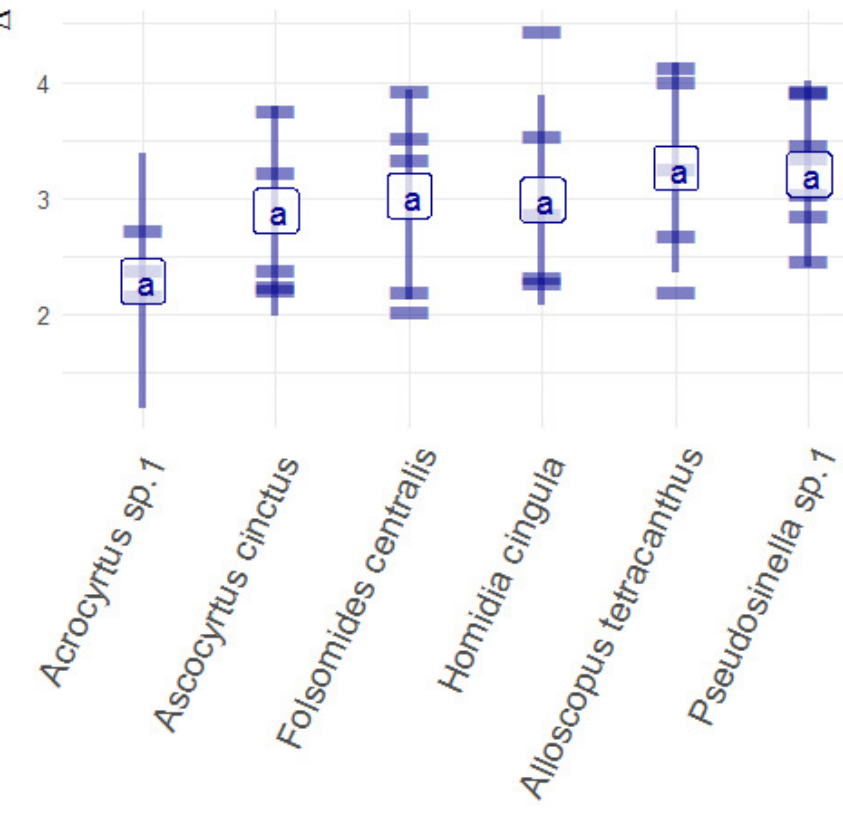

6

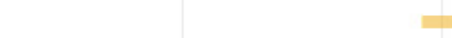

2
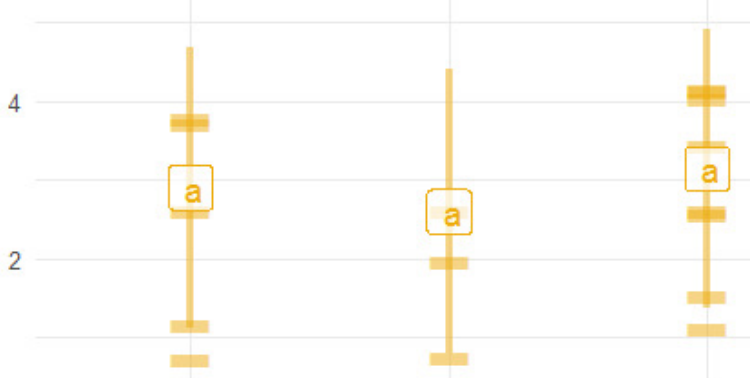

Species
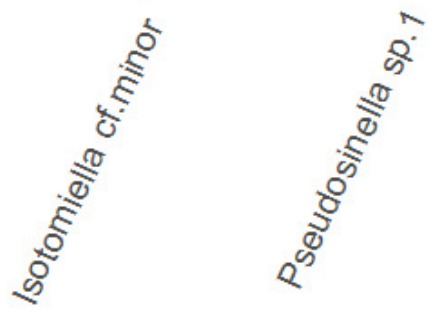


\section{Figure 3}

Differences of $\Delta^{15} \mathrm{~N}$ values of Collembola in different land-use systems (rainforest, jungle rubber, rubber and oil palm plantations)

Differences of $\Delta^{15} \mathrm{~N}$ values of Collembola in different land-use systems: (A) rainforest, (B) jungle rubber, (C) rubber and (D) oil palm plantation; model-estimated means (Ismeans) with standard deviation. Horizontal stripes represent individual measurements. Only species with more than three replicates per land-use system were analyzed (see Methods). Isotope values of each species in each land-use system with the same letter are not significantly different according to Tukey's honestly significant difference test $(p>0.05)$ 


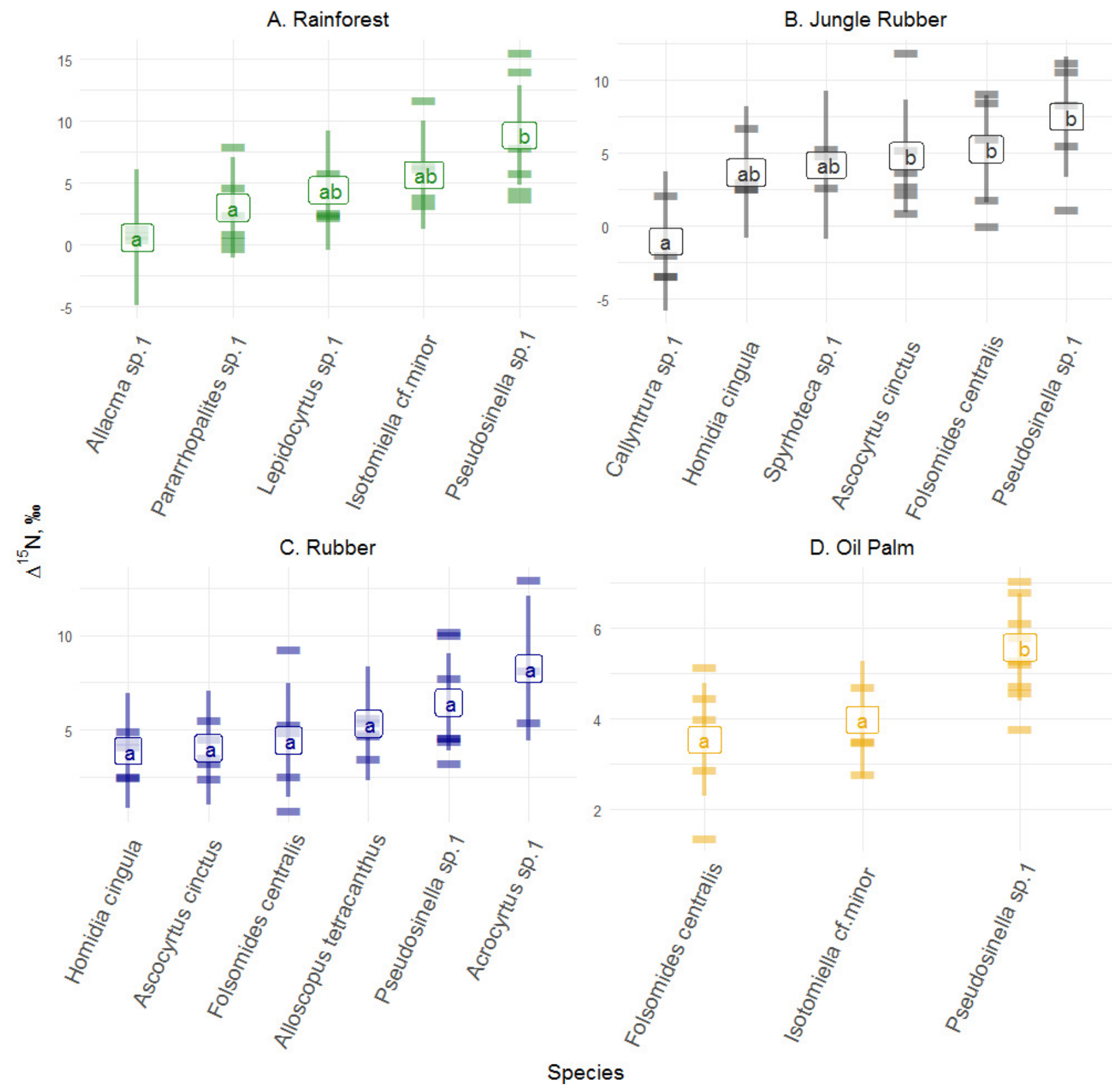




\section{Figure 4}

Stable isotope niches of four Collembola life forms in rainforest, jungle rubber, rubber, and oil palm plantations

Stable isotope niches of four Collembola life forms in (A) rainforest, (B) jungle rubber, (C) rubber, and (D) oil palm plantations. Ellipses denote $60 \%$ confidence intervals, different life forms are shown in color (eudaphic $=$ blue, epedaphic $=$ grey, hemiedaphic $=$ yellow, atmobiotic $=$ green). Large colored dots represent means of land-use systems, small points represent individual measurements

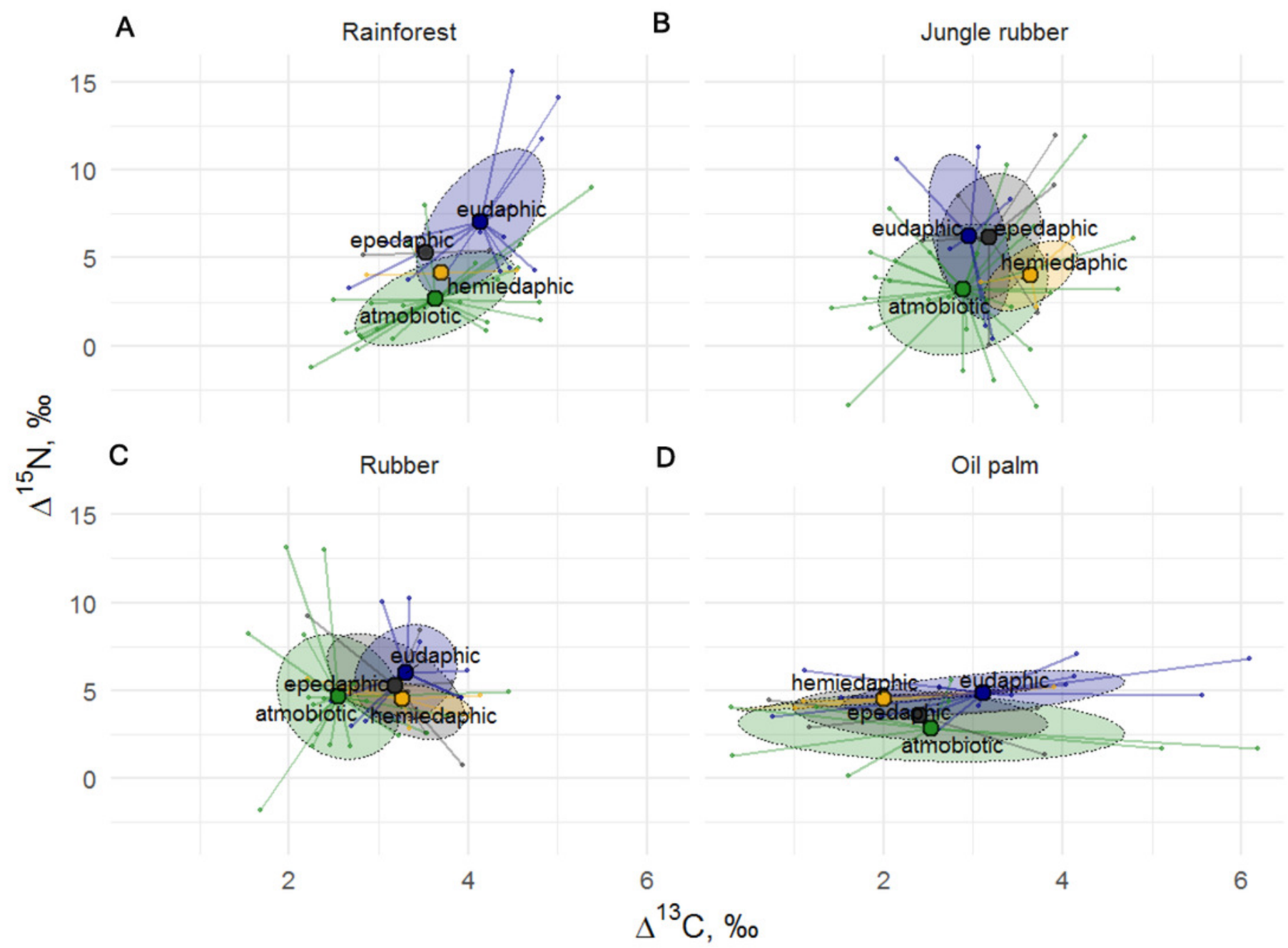




\section{Figure 5}

Stable isotope niche of Collembola families in rainforest, jungle rubber, rubber, and oil palm plantations

Stable isotope niche of Collembola families in (A) rainforest, (B) jungle rubber, (C) rubber, and (D) oil palm plantations. Ellipses denote $60 \%$ intervals, different families are shown in color $($ Paronellidae $=$ blue, Isotomidae $=$ green, Symphypleona $=$ purple, Entomobryidae $=$ red; Symphypleona comprises the families Sminthuridae, Sminthiridididae, Dycirtomidae and Katiannidae). Large colored dots represent means of land-use systems, small points represent individual measurements

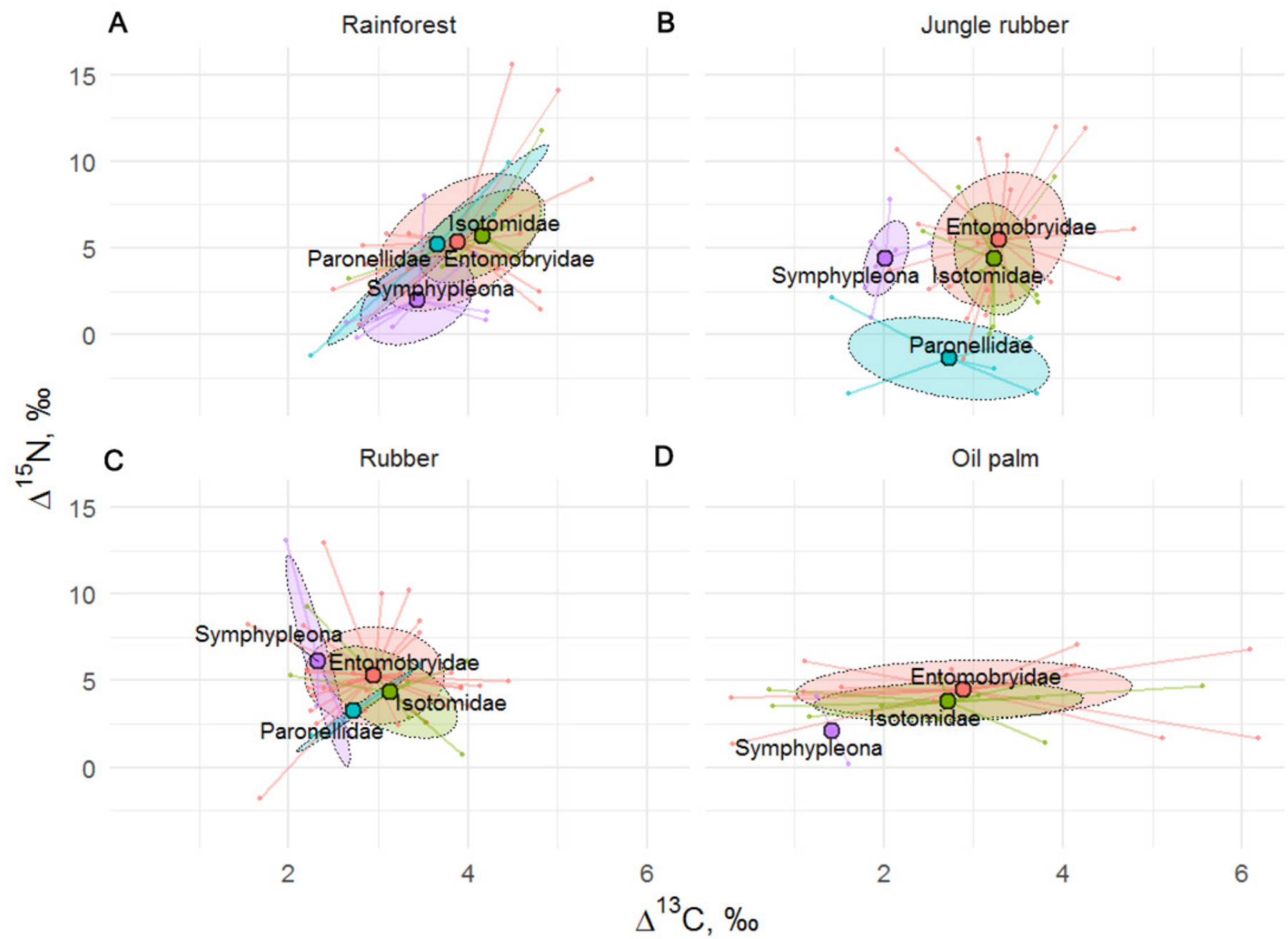

